\title{
Editorial
}

\section{Multibody Systems with Flexible Elements}

\author{
Marin Marin 1,*(D), Dumitru Băleanu 2,3,4,*(D) and Sorin Vlase 5,6,*(D) \\ 1 Department of Mathematics and Computer Science Transilvania, University of Brașov, \\ 500036 Brașov, Romania \\ 2 Department of Mathematics, Faculty of Art and Sciences, Cankaya University, Ankara 0630, Turkey \\ 3 Institute of Space Sciences, 077125 Bucharest-Magurele, Romania \\ 4 Department of Medical Research, China Medical University Hospital, Taichung 40402, Taiwan \\ 5 Department of Mechanical Engineering, Faculty of Mechanical Engineering, \\ Transilvania University of Brașov, 500036 Brașov, Romania \\ 6 Romanian Academy of Technical Science, Calea Victoriei, 700506 Bucharest, Romania \\ * Correspondence: m.marin@unitbv.ro (M.M.); dumitru.baleanu@gmail.com (D.B.); svlase@unitbv.ro (S.V.); \\ Tel.: +40-722-643020 (M.M.)
}

check for

updates

Citation: Marin, M.; Băleanu, D.; Vlase, S. Multibody Systems with Flexible Elements. Symmetry 2021, 13, 1359. https://doi.org/10.3390/ sym 13081359

Received: 5 July 2021

Accepted: 6 July 2021

Published: 27 July 2021

Publisher's Note: MDPI stays neutral with regard to jurisdictional claims in published maps and institutional affiliations.

Copyright: (C) 2021 by the authors. Licensee MDPI, Basel, Switzerland. This article is an open access article distributed under the terms and conditions of the Creative Commons Attribution (CC BY) license (https:// creativecommons.org/licenses/by/ $4.0 /)$.

\section{Introduction}

The formalism of multibody systems offers a means of computer-assisted algorithmic analysis and a means of simulating and optimizing an arbitrary movement of a possible high number of elastic bodies in the connection. The domains where researchers apply these methods are robotics, simulation of the dynamics of vehicles, biomechanics, aerospace engineering (helicopters, the behavior of cars in the gravitational field), internal combustion engines, gearboxes, transmissions, mechanisms, the cellulose industry, simulation of particle behavior (granulated particles and molecules), dynamic simulation, military applications, computer games, medicine, and rehabilitation. As a result, multibody systems have become widely used in all industries, such as in automotive engineering, airspace engineering, construction, and manufacturing [1-8]. It is for these reasons that there is continuous research into the development of the field. Some of this research is presented in this volume, in which a large group of researchers will present their latest findings. We hope that researchers will find an interesting and useful volume of information for their future work, but that the results will also be used by engineers for practical applications.

\section{Statistics of the Special Issue}

The statistics of papers called for this Special Issue, related to published or rejected items, are as follows [9-23]: 26 total submissions, of which 15 were published (57.6\%) and 11 rejected (42.3\%). The authors' geographical distribution is shown in Table 1, and it can be seen that the 38 authors are from 9 different countries. Note that it is usual for a paper to be written by more than one author, and for authors to collaborate with authors with different affiliations or multiple affiliations.

Table 1. Geographic distribution of authors by country.

\begin{tabular}{cc}
\hline Country & Number of Authors \\
\hline Romania & 22 \\
Saudi Arabia & 3 \\
India & 2 \\
China & 5 \\
Egypt & 3 \\
Vietnam & 2 \\
Iran & 2 \\
UK & 2 \\
Poland & 1 \\
\hline
\end{tabular}




\section{Authors of the Special Issue}

The authors of this Special Issue and their main affiliations are summarized in Table 2, and it can be seen that there are three authors on average per manuscript.

Table 2. Affiliations and bibliometric indicators for authors.

\begin{tabular}{|c|c|c|}
\hline Author & Affiliation & References \\
\hline Marilena Ghitescu & Transilvania University of Brasov, Romania & {$[9,12,13]$} \\
\hline Ioan-Marius Ghitescu & Transilvania University of Brasov, Romania & {$[9,12,13]$} \\
\hline Sorin Vlase & $\begin{array}{c}\text { Transilvania University of Brasov, Romania } \\
\text { Technical Sciences Academy of Romania, B-dul Dacia 26, } 030167 \\
\text { Bucharest, Romania }\end{array}$ & {$[9,13,18,19,22]$} \\
\hline Paul Nicolae Borza & Transilvania University of Brasov, Romania & {$[9,12,13]$} \\
\hline Octavian Postavaru & $\begin{array}{c}\text { Center for Research and Training in Innovative Techniques of Applied } \\
\text { Mathematics in Engineering, University Politehnica of Bucharest, } \\
060042 \text { Bucharest, Romania }\end{array}$ & [10] \\
\hline Antonela Toma & $\begin{array}{c}\text { Center for Research and Training in Innovative Techniques of Applied } \\
\text { Mathematics in Engineering, University Politehnica of Bucharest, } \\
060042 \text { Bucharest, Romania }\end{array}$ & [10] \\
\hline Joseph Dianavinnarasi & $\begin{array}{c}\text { Department of Mathematics, Alagappa University, Karaikudi } 630 \text { 004, } \\
\text { India }\end{array}$ & [11] \\
\hline Ramachandran Raja & $\begin{array}{l}\text { Ramanujan Centre for Higher Mathematics, Alagappa University, } \\
\text { Karaikudi } 630 \text { 004, India }\end{array}$ & [11] \\
\hline Jehad Alzabut & $\begin{array}{c}\text { Department of Mathematics and General Sciences, Prince Sultan } \\
\text { University, Riyadh 12435, Saudi Arabia }\end{array}$ & [11] \\
\hline Michał Niezabitowski & $\begin{array}{c}\text { Department of Automatic Control and Robotics, Faculty of Automatic } \\
\text { Control, Electronics and Computer Science, Silesian University of } \\
\text { Technology, Akademicka 16, 44-100 Gliwice, Poland }\end{array}$ & [11] \\
\hline Ovidiu Bagdasar & $\begin{array}{c}\text { Department of Electronics, Computing and Mathematics, University of } \\
\text { Derby, Derby DE22 1GB, UK }\end{array}$ & {$[11]$} \\
\hline Marin Marin & Transilvania University of Brasov, Romania & {$[12,20,22]$} \\
\hline Maria Luminita Scutaru & Transilvania University of Brasov, Romania & {$[12,19,22]$} \\
\hline Calin Itu & Transilvania University of Brasov, Romania & {$[14]$} \\
\hline Polidor Bratu & ICECON SA, Bucharest, Romania & {$[14,15]$} \\
\hline Dorin Lixandroiu & Transilvania University of Brasov, Romania & [14] \\
\hline Chen Wang & $\begin{array}{l}\text { Key Laboratory of Exploration Mechanism of the Deep Space Planet } \\
\text { Surface, Ministry of Industry and Information Technology, Nanjing } \\
\text { University of Aeronautics and Astronautics, Nanjing 211100, China }\end{array}$ & [16] \\
\hline Jinbao Chen & $\begin{array}{l}\text { Key Laboratory of Exploration Mechanism of the Deep Space Planet } \\
\text { Surface, Ministry of Industry and Information Technology, Nanjing } \\
\text { University of Aeronautics and Astronautics, Nanjing 211100, China }\end{array}$ & [16] \\
\hline Shan Jia & $\begin{array}{l}\text { Key Laboratory of Exploration Mechanism of the Deep Space Planet } \\
\text { Surface, Ministry of Industry and Information Technology, Nanjing } \\
\text { University of Aeronautics and Astronautics, Nanjing 211100, China }\end{array}$ & {$[16]$} \\
\hline Heng Chen & $\begin{array}{l}\text { Field Engineering College, Army Engineering University of PLA, } \\
\text { Nanjing 210001, China }\end{array}$ & [16] \\
\hline Attila Gerocs & $\begin{array}{c}\text { Doctoral School of Mechanical Engineering, "Eftimie Murgu” } \\
\text { University of Resita, } 320085 \text { Resita, Romania }\end{array}$ & [17] \\
\hline Gilbert-Rainer Gillich & $\begin{array}{c}\text { Doctoral School of Mechanical Engineering, "Eftimie Murgu" } \\
\text { University of Resita, } 320085 \text { Resita, Romania }\end{array}$ & [17] \\
\hline Dorian Nedelcu & $\begin{array}{l}\text { Doctoral School of Mechanical Engineering, "Eftimie Murgu" } \\
\text { University of Resita, } 320085 \text { Resita, Romania }\end{array}$ & [17] \\
\hline
\end{tabular}


Table 2. Cont.

\begin{tabular}{|c|c|c|}
\hline Author & Affiliation & References \\
\hline Zoltan-Iosif Korka & $\begin{array}{c}\text { Doctoral School of Mechanical Engineering, "Eftimie Murgu" } \\
\text { University of Resita, } 320085 \text { Resita, Romania }\end{array}$ & [17] \\
\hline $\begin{array}{l}\text { Gina Diana Musca } \\
\text { (Anghelache) }\end{array}$ & $\begin{array}{l}\text { Engineering and Agronomy Faculty in Braila, Research Center for } \\
\text { Mechanics of Machines and Technological Equipments, “Dunarea de } \\
\text { Jos" University of Galati, } 810017 \text { Braila, Romania }\end{array}$ & [18] \\
\hline Carmen Debeleac & $\begin{array}{l}\text { Engineering and Agronomy Faculty in Braila, Research Center for } \\
\text { Mechanics of Machines and Technological Equipments, “Dunarea de } \\
\text { Jos" University of Galati, } 810017 \text { Braila, Romania }\end{array}$ & [18] \\
\hline Gabriel Leonard Mitu & COMAT, SA, str. Zizinului, nr.111, 500002 Brasov, Romania & [19] \\
\hline Eliza Chircan & $\begin{array}{c}\text { Department of Mechanical Engineering, Transilvania University of } \\
\text { Brașov, B-dulEroilor 20, } 500036 \text { Brașov, Romania }\end{array}$ & \\
\hline Aatef Hobiny & $\begin{array}{c}\text { Nonlinear Analysis and Applied Mathematics Research Group } \\
\text { (NAAM), Mathematics Department, King Abdulaziz University, } \\
\text { Jeddah 21521, Saudi Arabia }\end{array}$ & [20] \\
\hline Faris Alzahrani & $\begin{array}{c}\text { Nonlinear Analysis and Applied Mathematics Research Group } \\
\text { (NAAM), Mathematics Department, King Abdulaziz University, } \\
\text { Jeddah 21521, Saudi Arabia }\end{array}$ & [20] \\
\hline Ibrahim Abbas & $\begin{array}{l}\text { Mathematics Department, Faculty of Science, Sohag University, Sohag } \\
\text { 82524, Egypt }\end{array}$ & [20] \\
\hline Ahmed A. El-Deeb & $\begin{array}{l}\text { Department of Mathematics, Faculty of Science, Al-Azhar University, } \\
\text { Nasr City, Cairo 11884, Egypt }\end{array}$ & [21] \\
\hline Samer D. Makharesh & $\begin{array}{l}\text { Department of Mathematics, Faculty of Science, Al-Azhar University, } \\
\text { Nasr City, Cairo 11884, Egypt }\end{array}$ & {$[21]$} \\
\hline Dumitru Baleanu & $\begin{array}{c}\text { Cankaya University, Ankara, Turkey } \\
\text { Institute of Space Sciences, Bucharest-Magurele, Romania } \\
\text { Department of Medical Research, China Medical University Hospital, } \\
\text { China Medical University, Taichung 40402, Taiwan, China }\end{array}$ & {$[10,12,21,23]$} \\
\hline Iuliu Negrean & $\begin{array}{c}\text { Technical Sciences Academy of Romania; B-dul Dacia 26, } 030167 \\
\text { Bucharest, Romania } \\
\text { Department of Mechanical Systems Engineering, Technical University } \\
\text { of Cluj-Napoca, Str. Memorandumului 28, } 400114 \text { Cluj-Napoca, } \\
\text { Romania }\end{array}$ & [22] \\
\hline $\begin{array}{l}\text { Mohammad Reza } \\
\text { Mahmoudi }\end{array}$ & $\begin{array}{c}\text { Institute of Research and Development, Duy Tan University, Da Nang } \\
\text { 550000, Vietnam } \\
\text { Department of Statistics, Faculty of Science, Fasa University, Fasa, Fars } \\
\text { 7461686131, Iran }\end{array}$ & [23] \\
\hline Roya Nasirzadeh & $\begin{array}{l}\text { Department of Statistics, Faculty of Science, Fasa University, Fasa, Fars } \\
\text { 7461686131, Iran }\end{array}$ & [23] \\
\hline Kim-Hung Pho & $\begin{array}{c}\text { Fractional Calculus, Optimization and Algebra Research Group, } \\
\text { Faculty of Mathematics and Statistics, Ton Duc Thang University, Ho } \\
\text { Chi Minh City 72915, Vietnam }\end{array}$ & [23] \\
\hline
\end{tabular}

\section{Brief Overview of the Contributions to the Special Issue}

The analysis of the topics identifies or summarizes the research undertaken. This section classifies the manuscripts according to the topics proposed in the Special Issue. There are three topics that are dominant, namely: modeling of the multibody system with symmetries, symmetry in applied mathematics and analytical methods in the symmetric multibody systems. 
Author Contributions: Conceptualization, M.M., D.B. and S.V.; methodology, M.M., D.B. and S.V.; software, M.M., D.B. and S.V.; validation, M.M., D.B. and S.V.; formal analysis, M.M., D.B. and S.V.; investigation, M.M., D.B. and S.V.; resources, M.M., D.B. and S.V.; data curation, M.M., D.B. and S.V.; writing-original draft preparation, S.V.; writing—review and editing, M.M., D.B. and S.V.; visualization, M.M., D.B. and S.V.; supervision, M.M., D.B. and S.V.; project administration, M.M., D.B. and S.V. All authors have read and agreed to the published version of the manuscript."

Funding: This research received no external funding.

Institutional Review Board Statement: Not applicable.

Informed Consent Statement: Not applicable.

Data Availability Statement: Not applicable.

Acknowledgments: Not applicable.

Conflicts of Interest: The authors declare no conflict of interest.

\section{References}

1. Vlase, S.; Nastac, C.; Marin, M.; Mihălcică, M. A Method for the Study of the Vibration of Mechanical Bars Systems with Symmetries. Acta Tech. Napoc. Ser. Appl. Math. Mech. Eng. 2017, 60, 539-544.

2. Vlase, S. A Method of Eliminating Lagrangian Multipliers from the Equation of Motion of Interconnected Mechanical Systems. J. Appl. Mech. Trans. ASME 1987, 54, 235-237. [CrossRef]

3. Scutaru, M.L.; Vlase, S.; Marin, M.; Modrea, A. New analytical method based on dynamic response of planar mechanical elastic systems. Bound. Value Probl. 2020, 2020, 104. [CrossRef]

4. Vlase, S.; Marin, M.; Öchsner, A. Considerations of the transverse vibration of a mechanical system with two identical bars. Proc. Inst. Mech. Eng. Part. L J. Mater. Des. Appl. 2019, 233, 1318-1323. [CrossRef]

5. Marin, M.; Vlase, S.; Paun, M. Considerations on double porosity structure for micropolar bodies. AIP Adv. 2015, 5, 037113. [CrossRef]

6. Khan, A.A.; Bukhari, S.R.; Marin, M.; Ellahi, R. Effects of chemical reaction on third-grade mhd fluid flow under the influence of heat and mass transfer with variable reactive index. Heat Transf. Res. 2019, 50, 1061-1080. [CrossRef]

7. Saeed, T.; Abbas, I.; Marin, M. A GL Model on Thermo-Elastic Interaction in a Poroelastic Material Using Finite Element Method. Symmetry 2020, 12, 488. [CrossRef]

8. Zhang, L.; Bhatti, M.M.; Marin, M.; Mekheimer, K.S. Entropy Analysis on the Blood Flow through Anisotropically Tapered Arteries Filled with Magnetic Zinc-Oxide (ZnO) Nanoparticles. Entropy 2020, 22, 1070. [CrossRef]

9. Ghitescu, M.; Ghitescu, I.-M.; Vlase, S.; Borza, P. Experimental Dynamic Rigidity of an Elastic Coupling with Bolts. Symmetry 2021, 13, 989. [CrossRef]

10. Postavaru, O.; Toma, A. Symmetries for Nonconservative Field Theories on Time Scale. Symmetry 2021, 13, 552. [CrossRef]

11. Dianavinnarasi, J.; Raja, R.; Alzabut, J.; Niezabitowski, M.; Bagdasar, O. Controlling Wolbachia Transmission and Invasion Dynamics among Aedes Aegypti Population via Impulsive Control Strategy. Symmetry 2021, 13, 434. [CrossRef]

12. Ghițescu, I.-M.; Scutaru, M.L.; Ghițescu, M.; Borza, P.N.; Marin, M. New Command Mechanism of Flaps and Wings of a Light Sport Aircraft. Symmetry 2021, 13, 221. [CrossRef]

13. Ghiţescu, M.; Ghițescu, I.-M.; Borza, P.; Vlase, S. A New Optimized Solution for A Flexible Coupling with Bolts Used in the Mechanical Transmissions. Symmetry 2021, 13, 171. [CrossRef]

14. Itu, C.; Bratu, P.; Borza, P.N.; Vlase, S.; Lixandroiu, D. Design and Analysis of Inertial Platform Insulation of the ELI-NP Project of Laser and Gamma Beam Systems. Symmetry 2020, 12, 1972. [CrossRef]

15. Bratu, P. Multibody System with Elastic Connections for Dynamic Modeling of Compactor Vibratory Rollers. Symmetry 2020, 12, 1617. [CrossRef]

16. Wang, C.; Chen, J.; Jia, S.; Chen, H. Parameterized Design and Dynamic Analysis of a Reusable Launch Vehicle Landing System with Semi-Active Control. Symmetry 2020, 12, 1572. [CrossRef]

17. Gerocs, A.; Gillich, G.-R.; Nedelcu, D.; Korka, Z.-I. A Multibody Inertial Propulsion Drive with Symmetrically Placed Balls Rotating on Eccentric Trajectories. Symmetry 2020, 12, 1422. [CrossRef]

18. Anghelache, G.D.M.; Debeleac, C.; Vlase, S. Experimental Assessments on the Evaluation of Wire Rope Characteristics as Helical Symmetrical Multi-body Ensembles. Symmetry 2020, 12, 1231. [CrossRef]

19. Mitu, G.L.; Chircan, E.; Scutaru, M.L.; Vlase, S. Kane's Formalism Used to the Vibration Analysis of a Wind Water Pump. Symmetry 2020, 12, 1030. [CrossRef]

20. Hobiny, A.; Alzahrani, F.; Abbas, I.; Marin, M. The Effect of Fractional Time Derivative of Bioheat Model in Skin Tissue Induced to Laser Irradiation. Symmetry 2020, 12, 602. [CrossRef] 
21. El-Deeb, A.A.; Makharesh, S.D.; Baleanu, D. Dynamic Hilbert-Type Inequalities with Fenchel-Legendre Transform. Symmetry 2020, 12, 582. [CrossRef]

22. Vlase, S.; Negrean, I.; Marin, M.; Scutaru, M.L. Energy of Accelerations Used to Obtain the Motion Equations of a ThreeDimensional Finite Element. Symmetry 2020, 12, 321. [CrossRef]

23. Mahmoudi, M.R.; Nasirzadeh, R.; Baleanu, D.; Pho, K.-H. The Properties of a Decile-Based Statistic to Measure Symmetry and Asymmetry. Symmetry 2020, 12, 296. [CrossRef] 